\title{
Bioaccumulation of Heavy Metals in Water and Algae of Mukkombu in the River Cauvery System, Tiruchirappalli District, Tamil Nadu, India
}

\author{
R. Anbalagan and R. Sivakami* \\ Department of Zoology, Arignar Anna Govt. Arts College, Musiri -621211, Tamil Nadu, India \\ *Corresponding author
}

\begin{abstract}
A B S T R A C T
Keywords

Heavy metals, Fresh water river system,

Accumulation,

Algae

\section{Article Info}

Accepted:

10 December 2017

Available Online:

10 January 2018

Today water discharges from industries are the major causes of water pollution resulting in destabilized ecosystems. Hence, it is necessary to monitor the levels of these pollutants as well as develop technologies for the treatment of waste water. Hence, the present study was attempted to analyse the commonly occurring heavy metals in water and organisms in two stations, Musiri and Mukkombu of the River Cauvery. Results indicate that iron recorded the highest levels followed by zinc, copper, lead and cadmium with regard to metal content in organisms, Nitzshua sigma recorded the least metal content, while Spirogyra quininarecorded highest $\mathrm{Cu}$ content and Oscillatorialimosa the highest $\mathrm{Cd}$ content. However, Chlorella vulgaris recorded the highest content for $\mathrm{Pb}, \mathrm{Zn}$ and $\mathrm{Fe}$ for both the stations.Among the two Stations, Station-II (Mukkombu) recorded the highest concentration of all the metals in both water as well as organisms. Thus, it is obvious that metals are taken up by algae.
\end{abstract}

\section{Introduction}

The availability of water is an indispensable factor for preventing diseases and improving the quality of life (Oluduro and Adewoye, 2007). The water quality of an aquatic environment arises from its physical, chemical and biological interactions (Dec., 1989).

Aquatic ecosystem balance gets affected by human activities resulting in pollution leading to drastic deleterious effects on the system. Today waste water discharge from industries are the major causes of water pollution leading to increased oxygen demand and nutrient loading resulting in destabilized aquatic systems (Morrison et al., 2001). Among the pollutants, heavy metal discharges endanger ecosystem diversity due to development of mining, smelting and other industrial activities.

Even though some metals are required as micronutrients, in organisms their increased concentration becomes toxic to most organisms (Nies, 1999; Lasat, 2002; Tangahu et al., 2011; Jaiswar et al., 2015). Hence, it is necessary to monitor their levels in aquatic systems as well as develop technologies for the treatment of waste water. 


\section{Materials and Methods}

The filamentous cyanoabacteria Oscillatoria limosa was obtained from the Mukkombu of the River Cauvery. The cyanobacteria was washed twice with tap water and then with double distilled water thoroughly to eliminate adhering foreign particles like sand and debris. The collected cyanobacterial samples were transferred to conical flasks with BG 11 medium (Rippka et al., 1979). The washed biomass was first air dried for 24 hours followed by using an oven at $80^{\circ} \mathrm{C}$ till constant weight was recorded. The dried biomass was then ground and sieved through a sieve $(2 \mathrm{~mm})$ and stored in polyethylene bottles.

Batch equilibrium experiments were performed at room temperature in $250 \mathrm{ml}$ Erlenmeyer glass flasks containing aqueous solution of $\mathrm{Cd}, \mathrm{Hg}$ and $\mathrm{Pb}$ of known concentrations $\left(20,40,60\right.$ and $\left.80 \mathrm{mg}^{-1}\right)$ prepared using analytical grade cadmium nitrate $\left[\mathrm{Cd}\left(\mathrm{NO}_{3}\right)_{2}\right]$, mercuric chloride $\left(\mathrm{HgCl}_{2}\right)$ and lead nitrate $\left[\mathrm{Pb}\left(\mathrm{NO}_{3}\right)_{2}\right]$. An accurately weighed $250 \mathrm{mg}$ portion of biomass was added to each flask and the mixtures were agitated on a rotary shaker at $180 \mathrm{rpm}$ for different time intervals $(30,60,90$ and 120 $\mathrm{min})$. Controls for each concentration without the addition of heavy metals were also maintained. After the respective agitation period, the solutions were separated from the biomass by filtration and subjected to further analysis. All the biosorption experiments were conducted in triplicates to substantiate the results. The data shown are the mean values of these replicate determinations. Heavy metal content in all the filtrates was quantified using inductively coupled plasma-optical emission spectroscopy (ICP-OES, Perkin Elmer Optima-3300 RL) at Bangalore. The amount of metal sorbed at equilibrium $\left(\mathrm{mg} \mathrm{g}^{-1}\right)$ which represents the heavy metal uptake was calculated from the difference in metal concentration in the aqueous phase before and after absorption according to Shaik et al., (2006).

\section{Results and Discussion}

The results of the heavy metal content in the water and the organisms studied are presented in Tables 1 and 2. As evident from Table 1, the heavy metal content in waters of Station-I (Musiri) recorded levels ranging from 0.58 to $7.7 \mathrm{mg} / \mathrm{l}$. While the lowest metal content in water was recorded by cadmium, the highest level of $7.7 \mathrm{mg} / \mathrm{l}$ was recorded by iron. In Station-II (Mukkombu), the level of heavy metals in water was found to range from 0.70 to $9.45 \mathrm{mg} / \mathrm{l}$. However, the minimum level here also was again noticed by cadmium and the maximum level by iron.

With regard to the level of heavy metals in organisms in Station-I, copper content was found to range from 10.6 to $50.2 \mu \mathrm{g} / \mathrm{g} / \mathrm{dwt}$. The minimal copper content was found in Nitzschia sigma and themaximum of Spirogyra quinae. The other two organisms (Oscillatorialimosa- $11.2 \mu \mathrm{g} / \mathrm{g} / \mathrm{dwt}$ and Chlorella vulgaris- $43 \mu \mathrm{g} / \mathrm{g} / \mathrm{dwt}$ ) recorded values in between. In Station-II, the copper content in organisms was found to range from 15.02 to $69.64 \mu \mathrm{g} / \mathrm{g} / \mathrm{dwt}$. Here again, the minimal level was recorded by $N$. sigma while the maximum was recorded by S. quinina.

Cadmium levels on the other hand was found to range from 2.4 (N. sigma) to $5.7 \mu \mathrm{g} / \mathrm{g} / \mathrm{dwt}$ (S. quinina) in Station-I and from 35 (C. vulgaris) to $7.41 \mu \mathrm{g} / \mathrm{g} / \mathrm{dwt}$ in $O$. limosa. A perusal of the lead levels reveals that in Station-I it ranged from 9.8 (N. sigma) to 32.6 $\mu \mathrm{g} / \mathrm{g} / \mathrm{dwt}$ (C. vulgaris) and in Station-II from 11.84 ( N. sigma) to $38.1 \mathrm{mg} / \mathrm{g} / \mathrm{dwt}$ ( $C$. vulgaris). With regard to zinc, $N$. sigma recorded the lowest level $(46.2 \mu \mathrm{g} / \mathrm{g} / \mathrm{dwt})$ and C. vulgaris the highest level $(10.2 \mu \mathrm{g} / \mathrm{g} / \mathrm{dwt})$ in Station-I. In Station-II also, N. sigma 
recorded the lowest level $(57.26 \mu \mathrm{g} / \mathrm{g} / \mathrm{dwt})$ and $C$. vulgaris, the highest level (128.1 $\mu \mathrm{g} / \mathrm{g} / \mathrm{dwt})$. On the other hand, N. sigma recorded the lowest level of iron (134.6 $\mu \mathrm{g} / \mathrm{g} / \mathrm{dwt}$ ), while $C$. vulgaris recorded the highest level $(180 \mu \mathrm{g} / \mathrm{g} / \mathrm{dwt})$ in Station-I. In Station-II, the lowest level was recorded by $O$. limosa $(164.6 \mu \mathrm{g} / \mathrm{g} / \mathrm{dwt})$ even though the maximal level was again noticed in $C$. vulgaris $(191.6 \mu \mathrm{g} / \mathrm{g} / \mathrm{dwt})$.

Thus, an overall comparison of the heavy metal levels in water reveals that in Station-I, $\mathrm{Cd}$ recorded the lowest levels followed by lead, copper, zinc and iron while in Station-II, $\mathrm{Cd}$ recorded the lowest levels followed by $\mathrm{Cu}$, $\mathrm{Pb}, \mathrm{Zn}$ and $\mathrm{Fe}$. Thus in general, the order of heavy metal in terms of content was $\mathrm{Fe}>\mathrm{Zn}>$ $\mathrm{Cu}=\mathrm{Pb}>\mathrm{Cd}$. A perusal of literature reveals that Sreenivasan (1968) recorded only traces of iron in Chengleput Pond, while in Yercaud and Ooty lake, $2 \mathrm{mg} / \mathrm{l}$ (Sreenivasan, 1964). However, Malarvizhi (1989) recorded maximum Fe levels of $37.46 \mathrm{mg} / \mathrm{l}$ in Manur Pond. Thus the present study recorded levels which are comparable to the present study.
Nevertheless, Wetzel (1980) suggests that the quantity of total iron found in most typical or alkaline lakes varies from 50 to $200 \mathrm{mg} / \mathrm{l}$.

Chatterjee (2010) on the other hand recorded copper levels in water to reach $3.95 \mathrm{mg} / \mathrm{l}$ in Damodarriver, while Jainwar et al., (2015) recorded levels of $2.78 \mathrm{mg} / \mathrm{l}$ in Bhaunagar, Gujarat. A comparison of these levels with the present study reveals that the levels in the water of the present system is comparable with regard to $\mathrm{Pb}$, Malarvizhi (1989) recorded $\mathrm{Pb}$ level in water to reach $5.8 \mathrm{mg} / \mathrm{l}$ while Ustanada (2011) recorded $\mathrm{Pb}$ levels to reach $5.24 \mathrm{mg} / \mathrm{l}$, and Janwar et al., (2015) recorded levels in the range of $40.47 \mathrm{mg} / \mathrm{l}$ in Sihor tributary. However, Govindasamy (2007) recorded a level of $13.0 \mathrm{mg} / \mathrm{l}$ in River Palar. Comparing these levels with the present study reveals a comparatively lower level. As far as Zn levels were concerned, Malarvzhi (1989) recorded a level of $15.16 \mathrm{mg} / \mathrm{l}$ while Govindasamy (2007) recorded a level of 40.5 $\mathrm{mg} / \mathrm{l}$ and Janwar et al., (2015) recorded a level of $6.24 \mathrm{mg} / \mathrm{l}$. These levels are comparable with those obtained in the present study.

Table.1 Heavy metals concentration in water and organisms in Station-I

(Musiri, the River Cauvery)

\begin{tabular}{|c|c|c|c|c|c|c|}
\hline $\begin{array}{l}\text { S. } \\
\text { No. }\end{array}$ & $\begin{array}{c}\text { Heavy metals } \\
\text { (mg/l) }\end{array}$ & $\begin{array}{l}\text { Water } \\
(\mathrm{mg} / \mathrm{l})\end{array}$ & $\begin{array}{l}\text { Chlorella } \\
\text { vulgaris } \\
\text { ( } \mu \text { g/g/dwt) }\end{array}$ & $\begin{array}{l}\text { Spirogyra } \\
\text { quininae } \\
(\mu \mathrm{g} / \mathrm{g} / \mathrm{dwt})\end{array}$ & $\begin{array}{l}\text { Oscillatinal } \\
\text { inosa } \\
\text { ( } \mu \mathrm{g} / \mathrm{g} / \mathrm{dwt})\end{array}$ & $\begin{array}{l}\text { Nitzschia } \\
\text { sigma } \\
(\mu \mathrm{g} / \mathrm{g} / \mathrm{dwt})\end{array}$ \\
\hline 1. & $\mathrm{Cu}$ & 1.80 & 43.0 & 50.2 & 11.2 & 10.6 \\
\hline 2. & $\mathrm{Cd}$ & 0.58 & 2.6 & 3.1 & 5.7 & 2.4 \\
\hline 3. & $\mathrm{~Pb}$ & 1.30 & 32.6 & 15.6 & 30.6 & 9.8 \\
\hline 4. & $\mathrm{Zn}$ & 4.92 & 102.0 & 86.4 & 68.2 & 46.2 \\
\hline 5. & $\mathrm{Fe}$ & 7.70 & 180.0 & 172.0 & 150.4 & 134.6 \\
\hline
\end{tabular}


Table.2 Heavy metals concentration in water and organisms in Station-II (Mukkombu of the river Cauvery)

\begin{tabular}{|c|c|c|c|c|c|c|}
\hline $\begin{array}{l}\text { S. } \\
\text { No. }\end{array}$ & $\begin{array}{l}\text { Heavy metals } \\
(\mathrm{mg} / \mathrm{l})\end{array}$ & $\begin{array}{l}\text { Water } \\
\text { (mg/l) }\end{array}$ & $\begin{array}{c}\text { Chlorella } \\
\text { vulgaris } \\
\text { ( } \mu \mathrm{g} / \mathrm{g} / \mathrm{dwt})\end{array}$ & $\begin{array}{l}\text { Spirogyra } \\
\text { quininae } \\
\text { ( } \mu \mathrm{gg} / \mathrm{g} / \mathrm{dwt})\end{array}$ & $\begin{array}{l}\text { Oscillatina } \\
\text { linosa } \\
(\mu \mathrm{g} / \mathrm{g} / \mathrm{dwt})\end{array}$ & $\begin{array}{l}\text { Nitzschia } \\
\text { sigma } \\
\text { ( } \mu \mathrm{gg} / \mathrm{g} / \mathrm{dwt})\end{array}$ \\
\hline 1. & $\mathrm{Cu}$ & 2.6 & 48.6 & 69.64 & 18.83 & 15.02 \\
\hline 2. & $\mathrm{Cd}$ & 0.7 & 3.5 & 5.3 & 7.41 & 4.60 \\
\hline 3. & $\mathrm{~Pb}$ & 2.8 & 38.1 & 19.2 & 35.82 & 11.84 \\
\hline 4. & $\mathrm{Zn}$ & 6.5 & 128.1 & 104.6 & 98.4 & 57.26 \\
\hline 5. & $\mathrm{Fe}$ & 9.4 & 191.6 & 180.6 & 164.6 & 170.6 \\
\hline
\end{tabular}

With regard to the level of heavy metal content in organisms, Nitzschia sigma was found to have the least metal content for all the five heavy metals analyzed for both the stations even though exceptionally Chlorella vulgaris recorded minimal cadmium levels in Station-II. With regard to the maximal levels, Spirogyra quinine recorded highest copper levels in both stations (max. $69.64 \mu \mathrm{g} / \mathrm{g} / \mathrm{dwt}$ ) while highest cadmium level was noticed by Oscillatorialimosa in both stations (max. 7.41 $\mathrm{mg} / \mathrm{g} / \mathrm{dwt}$ ). However, the maximum levels of lead $(38.1 \mu \mathrm{g} / \mathrm{g} / \mathrm{dwt}$ ), zinc (max. 128.1 $\mu \mathrm{g} / \mathrm{g} / \mathrm{dwt})$ and iron $(191.6 \mu \mathrm{g} / \mathrm{g} / \mathrm{dwt})$ were uniformly recorded by Chlorella vulgaris. Thus, it appears that, $C$. vulgaris has the highest absorbance levels for $\mathrm{Pb}, \mathrm{Zn}$ and $\mathrm{Fe}$, while $O$. limosa, the highest level for $\mathrm{Cd}$ absorption and S. quininae the highest level of $\mathrm{Cu}$ absorption.

A perusal of literature revels that Rai et al., (2008) reported $\mathrm{Cu}$ accumulation in Oedogonium at $17.78 \mu \mathrm{g} / \mathrm{g}$, while AlHomaidan et al., (2011) reported Cladophora to accumulate $138.28 \mu \mathrm{g} / \mathrm{g}$ in a stream in Riyadh and Jaiswar (2015) recorded Oedogonium to accumulate $118.5 \mu \mathrm{g} / \mathrm{g}$ of $\mathrm{Cu}$ in fresh water system in Gujarat. However, Rajfur et al., (2011) reported a copper level of $47.5 \mu \mathrm{g} / \mathrm{g}$ in a river in Poland, while Janwar (2015) recorded a level of $22.11 \mu \mathrm{g} / \mathrm{g}$ in the same species. These levels of accumulation by algae when compared to the present study are on the lower side for copper absorption.

With reference to Cd, Rajfur et al., (2011) reported a level of $21.10 \mu \mathrm{g} / \mathrm{g}$ for Oedogonium and for Cladophora, $4.14 \mu \mathrm{g} / \mathrm{g}$. On the other hand, Al-Homaidan et al., (2011) recorded $\mathrm{Cd}$ levels of $1.08 \mu \mathrm{g} / \mathrm{g}$. Rajfor et al., (2011), however, noticed levels of $108.5 \mu \mathrm{g} / \mathrm{g}$ in Spyrogyra, while Janwar et al., (2015) recorded levels of $9.23 \mu \mathrm{g} / \mathrm{g}$ in Spirogyra. The levels obtained by Spyrogyra in the present study are again in the range noted by other workers.

With regard to $\mathrm{Pb}$, Eva and Jan (2001) recorded $7.9 \mu \mathrm{g} / \mathrm{g}$ in Cladophora from river Danube, while Dwivedi et al., (2006) reported $\mathrm{Pb}$ accumulation in Oscillatoria to a level of $142.81 \mu \mathrm{g} / \mathrm{g}$, while Janwar (2015) reported a level of $51.50 \mu \mathrm{g}$ in Oscillatoria. In the present study, the results recorded for Oscillatoria are on the lower side when compared to others.

With regard to zinc, Javed (2006) reported zinc to accumulate in plankton to a tune of $290.13 \mu \mathrm{g} / \mathrm{g}$, while Lokeshwari and Chandrappa (2007) recorded $82.0 \mu \mathrm{g} / \mathrm{g}$ in weed plants. Dwivedi (2006), however, recorded zinc to accumulate $277 \mu \mathrm{g} / \mathrm{g}$ in Oscillatoria while Jaiswar (2015) reported a level of $210.26 \mu \mathrm{g} / \mathrm{g}$ in Oscillatoria and 
$191.59 \mu \mathrm{g} / \mathrm{g}$ in Oedogonium. The present level of zinc in Oscillatoria recorded in this study is well below the levels noted by others.

Among the two Stations, Station-II recorded the highest concentration of all the metals in both water as well as organisms. Thus, it is obvious that metals are taken up by algae. Dwivedi (2012) suggested that the metal ions are absorbed over the cell surface very quickly and then transported slowly into the cytoplasm.

\section{References}

Al-Homaidan, A.A., Al-Ghariayem, A.A. and Alkhalifa, A. H. 2011. Green algae as bioindicator of heavy metals pollution in Wadi Hanlfah Stream Riyadh, Saudi Arabia. Irit. J. Water Res. Arid Environ, 1: 10-15.

Chattergi, S. K., Bhattacharjee, I. and Chandra, G. 2010. Water quality assessment near industrial site of Damodar River, India. Environ. Monit. Assess., 161: 177-189.

Das, N., Vimala, R. and Karthika, P. 2008. Biosorption of heavy metals - An overview. Indian Journal of Biotechnology, 7: 159-169.

Davis, T. A., Volesky, B. and Mucci, A. 2003. A review of the biochemistry of heavy metal biosorption by brown algae. Water Res., 37: 4311-4330.

Dwivedi, S., Tripathi, R. D., Rai, U. N., Srivastava, S., Mishra, S., Shukla, M. K., Gupta, A. K., Sinha, S., Baghel, V. S., and Gupta, D. K. 2006. Dominance of algae in Ganga water polluted through fly-ash leaching: metal bioaccumulation potential of selected algal species. Bull. Environ. Contam. Toxicol., 77: 427-436.

Eva, C. and Jan, M. 2001. Bioaccumulation of heavy metal by green algae Cladoplioraglomerata in a refinery sewage lagoon. Croat. Cherri. Acta., 74: 135-145.

Govindasamy, C., Sundaranmoorthy, M. and Kannan, L. 2007. Impact of municipal wastes on the river water quality of River Palar, Vellore, Tamil Nadu. Indian Hydrobiol., 10: 349-357.

Jaiswar, S., Kazi, M. A. and Mehta, S. 2015. Bioaccumulation of heavy metals by fresh water algal species of Bhavnagar, Gujarat, India. Journal of Environmental Biology, 36: 1361-1366

Javed, M., 2006. Studies on metal contamination levels in plankton and their role as biological indicator of water pollution in the River Ravi. Pak. J. Biol. Sci., 9: 313-317.

Khoo, K. M. and Ting, Y. P. 2001. Biosorption of gold by immobilized fungal biomass. Biochem. Eng. J., 8: 51-59.

Knorr, D., 1991. Recovery and utilization of chitin and chitosan in food processing waste management. Food Technol., 45: 114-122.

Lasat, M. M., 2002. Reviews and analyses: Phytoextraction at toxic metals - A review of biological mechanisms. $J$. Environ. Quai., 31: 109-120.

Lokeshwari, H. and Chandrappa, G. T. 2007. Effects of heavy metal contamination from anthropogenic sources on Dasarahalli tank, India. Lakes. Reserv. Res. Manage., 12: 121-128.

Malarvizhi, R., 1989. A comparative study of tropical lentic systems of India and Kenya with special reference to heavy metal and pesticide pollution. Ph.D. thesis, University of Madras, India.

Mofa, A. S., 1995. Plants proving their worth in toxic metal cleanup. Science, 269: 302-305.

Nayak, S. and Prasanna, R. 2007. Soil pH and its role in cyanobacterial abundance and diversity in rice field soils. Appl. Ecol. Environ. Res., 5: 1-6. 
Nies, D. H., 1999. Microbial heavy metal resistance. Appl. Microbiol. Biotechnol., 51: 730-750.

Nirmal Kumar, J. I. and Oommen, C. 2012. Removal of heavy metals by biosorption using freshwater alga Spirogyra hyalina. J. Environ. Biol., 33: 27-31.

Prasanna, R. and Nayak, S. 2007. Influence of diverse rice soil ecologies on cyanobacterial diversity and abundance. Wet. Ecol. Manag., 15: 127-134.

Rai, U.N., Dubey, S., Shukla, O. P., Dwivedi, S. and Tripathi, R. D. 2008. Screening and identification of early warning algal species for metal contamination in fresh water bodies polluted from point and non-point sources. Environ. Monit. Assess., 144: 469-481.

Rajfur, M., Klos, A. and Waclawek, M. 2011. Algae utilization in assessment of the large Turawa Lake (Poland) pollution with heavy metals. J. Environ. Sci. Health A. Tox. Hazard. Subst. Environ. Eng., 46: 1401-1408.

Rippka, R. J., Deruelles, J. B., Waterberry, M., Herdman, M. and Stainer, R. Y. 1979. Generic assignments, Strain Histories and Properties, Pure Cultures of Cynabacteria. J. Gen. Microbiol., 111: 1-61.

Shaik, B., Murthy, Z. V. P. and Jha, B. 2006. Biosorption of hexavalent chromium by chemically modified seaweed, Cystoseira indica. Chem. Eng. J., 137: 480-488.
Spinti, M., Zhuang, H. and Trujillo, E. M. 1995. Evaluation of immobilized biomass beads for removing heavy metals from wastewaters. Water Environ. Res., 67: 943-652.

Sreenivasan, A. 1964. Limnological studies and fish yield in three upland lakes of Madras State (India). Limnol. Oceanorgr., 2: 564-575.

Sreenivasan, A. 1968. The limnology and fish production in two ponds in Chingelput. Hydrobiol., 32: 131-144.

Srinath, T., Verma, T. P., Ramteke, W. and Garg, S. K. 2002. Chromium (VI) biosorption and bioaccumulation by chromate resistant bacteria. Chemosphere, 48: 427-435.

Suresh, B. and Ravishankar, G. A. 2004. Phytoremediation - A novel and promising approach for environmental clean-up. Crit. Rev. Biotechnol., 24: 97124.

Tangahu, B. V., Abdullah, S. R. S., Basri, H., Idris, M., Anuar, N. and Mukhllsin, M. 2011. A review on heavy metals (As, $\mathrm{Pb}$, and $\mathrm{Hg}$ ) uptake by plants through phytoremediation. Inter J. Chem. Engin., 2011: 1-31.

Ustunada, M., Erdugan, H., Yilmaz, S., Akgul, R. and Aysel, V. 2011. Seasonal concentrations of some heavy metals $(\mathrm{Cd}, \mathrm{Pb}, \mathrm{Zn}$, and $\mathrm{Cu})$ in Ulva rigida. $\mathrm{J}$. Agardh (Chlorophyta) from Dardanelles (Canakkale, Turkey). Environ. Monit. Assess., 177: 337-342.

\section{How to cite this article:}

Anbalagan, R. and Sivakami, R. 2018. Bioaccumulation of Heavy Metals in Water and Algae of Mukkombu in the River Cauvery System, Tiruchirappalli District, Tamil Nadu, India. Int.J.Curr.Microbiol.App.Sci. 7(01): 1067-1072. doi: https://doi.org/10.20546/ijcmas.2018.701.129 